\title{
The Role of Corticotropin-Releasing Factor in the Median Raphe Nucleus in Relapse to Alcohol
}

\author{
A. D. Lê, ${ }^{1,2,3}$ S. Harding, ${ }^{1}$ W. Juzytsch, ${ }^{1}$ P. J. Fletcher, ${ }^{1,2,3,4}$ and Y. Shaham ${ }^{5}$ \\ ${ }^{1}$ Department of Neuroscience, Center for Addiction and Mental Health, Toronto, Ontario, Canada M5S 2S1, Departments of \\ 2Pharmacology, ${ }^{3}$ Psychiatry, and ${ }^{4}$ Psychology, University of Toronto, Toronto, Ontario, Canada M5S 1A8, and ${ }^{5}$ Behavioral \\ Neuroscience Branch, National Institute on Drug Abuse Intramural Research Program, Baltimore, Maryland 21044
}

Using an animal model of drug relapse, we found that intermittent footshock stress reinstates alcohol seeking, an effect attenuated by the 5-HT reuptake blocker fluoxetine and by corticotropin-releasing factor (CRF) receptor antagonists. Here we studied the role of the 5-HT cell body region of the median raphe nucleus (MRN) and CRF receptors in this site in reinstatement of alcohol seeking. Rats were given alcohol in a two-bottle choice procedure (water vs alcohol) for $25 \mathrm{~d}$ and were then trained for $1 \mathrm{hr} / \mathrm{d}$ to press a lever for alcohol $(12 \% \mathrm{w} / \mathrm{v})$ for 23-30 d. Subsequently, lever pressing for alcohol was extinguished by terminating drug delivery for 5-9 d. Tests for reinstatement of alcohol seeking were then performed under extinction conditions. Intra-MRN infusions of $8-\mathrm{OH}-\mathrm{DPAT}$

In humans, stressful life events are reported to be associated with relapse to alcohol use after periods of abstinence (Sinha, 2001). The reasons for this association, however, are not known. Recently, we adapted an animal model of relapse to opioid and stimulant drugs, the reinstatement procedure (Stewart and de Wit, 1987), to study mechanisms underlying stress-induced relapse to alcohol seeking. We found that footshock stress potently reinstates drug seeking in alcohol-experienced rats (Le et al., 1998). This effect of stress on reinstatement of alcohol seeking was replicated independently (Martin-Fardon et al., 2000), and it extends findings from studies using cocaine- and heroin-trained rats (Shaham et al., 2000; Shalev et al., 2002).

In a study on the pharmacological basis of footshock-induced reinstatement of alcohol seeking, we found that the 5-HT reuptake blocker fluoxetine, but not the opioid antagonist naltrexone, attenuates this effect (Le et al., 1999). Subsequently, we found that the nonselective corticotropin-releasing factor (CRF) receptor antagonist $d$-Phe $\mathrm{CRF}$ and the selective $\mathrm{CRF}_{1}$ receptor antagonist CP-154,526 attenuate footshock-induced reinstatement of alcohol seeking (Le et al., 2000). In contrast, the removal of circulating corticosterone by adrenalectomy had no effect. These data are consistent with previous reports (Shaham et al., 1997; Erb et al., 1998) and support the notion that CRF mediates stress-induced reinstatement of drug seeking via its actions on extrahypothalamic sites.

\footnotetext{
Received March 21, 2002; revised June 3, 2002; accepted July 1, 2002.

This work was supported by a grant from the Ontario Mental Health Foundation (A.D.L., Y.S.). P.J.F. is a Career Scientist of the Ontario Ministry of Health.

Correspondence should be addressed to Dr. A. D. Lê, Department of Neurosciences, Center for Addiction and Mental Health, 33 Russell Street, Toronto, Ontario, Canada M5S 2S1. E-mail: anh_le@camh.net.

Copyright (ㄷ) 2002 Society for Neuroscience $0270-6474 / 02 / 227844-06 \$ 15.00 / 0$
}

[8-hydroxy-2-(di-n-propylamino)tetralin] (a 5- $\mathrm{HT}_{1 \mathrm{~A}}$ agonist that decreases 5-HT cell firing and release) reinstated alcohol seeking. Reinstatement of alcohol seeking also was observed after intra-MRN infusions of low doses of CRF (3-10 ng), which mimicked the effect of ventricular infusions of higher doses of the peptide (300-1000 ng). Finally, intra-MRN infusions of the CRF receptor antagonist $d$-Phe CRF (50 ng) blocked the effect of intermittent footshock (10 min) on reinstatement. These data suggest that an interaction between CRF and 5-HT neurons within the MRN is involved in footshock stress-induced reinstatement of alcohol seeking.

Key words: alcohol; corticotropin-releasing factor; reinstatement; relapse; serotonin; stress
Our data raise the possibility that CRF and 5-HT neurotransmission have opposite effects on footshock-induced reinstatement because increases in 5-HT levels by fluoxetine and blockade of CRF receptors had similar effects on relapse behavior. In agreement with this possibility, recent studies have shown that CRF infusions into the lateral ventricles or the cell body region of the dorsal raphe nucleus (DRN) predominantly inhibit (at low doses) 5-HT cell firing and release (Price et al., 1998; Kirby et al., 2000; Price and Lucki, 2001) (but see Lowry et al., 2000). The effects of CRF on 5-HT neurons of the median raphe nucleus (MRN) are not known.

In the present report, we examined the role of 5-HT and CRF in the raphe nuclei in reinstatement of alcohol seeking. We initially determined the effect of intra-MRN and intra-DRN infusions of a 5-HT $1 \mathrm{~A}$ agonist, 8-OH-DPAT [8-hydroxy-2-(di- $n$ propylamino)tetralin], which inhibits 5-HT cell firing (Price et al., 1998), on reinstatement of alcohol seeking. Based on these data, we further determined (1) the effect of intra-MRN infusions of CRF on reinstatement and (2) the effect of infusions of a CRF antagonist ( $d$-Phe CRF) into this brain site on footshock-induced reinstatement of alcohol seeking.

\section{MATERIALS AND METHODS}

Subjects. Male Wistar rats (150-175 gm; 41-44 d on arrival; Charles River Laboratories, Montreal, Canada) were housed individually with access to food and water ad libitum and were acclimated to the animal facility for several weeks before the start of the experiments. Temperature was maintained at $21^{\circ} \mathrm{C}$, and lights were on from 7:00 A.M. to 7:00 P.M. Procedures were conducted in accordance with the guidelines of the Canadian Council on Animal Care.

Surgery and injection procedures. Guide cannulas (24 gauge; Plastics One, Roanoke, VA) were implanted at a $20^{\circ}$ angle under pentobarbital anesthesia $(65 \mathrm{mg} / \mathrm{kg}$, i.p.). Stereotaxic coordinates (from bregma) for 


\section{A. Cannulae placements (from bregma)}
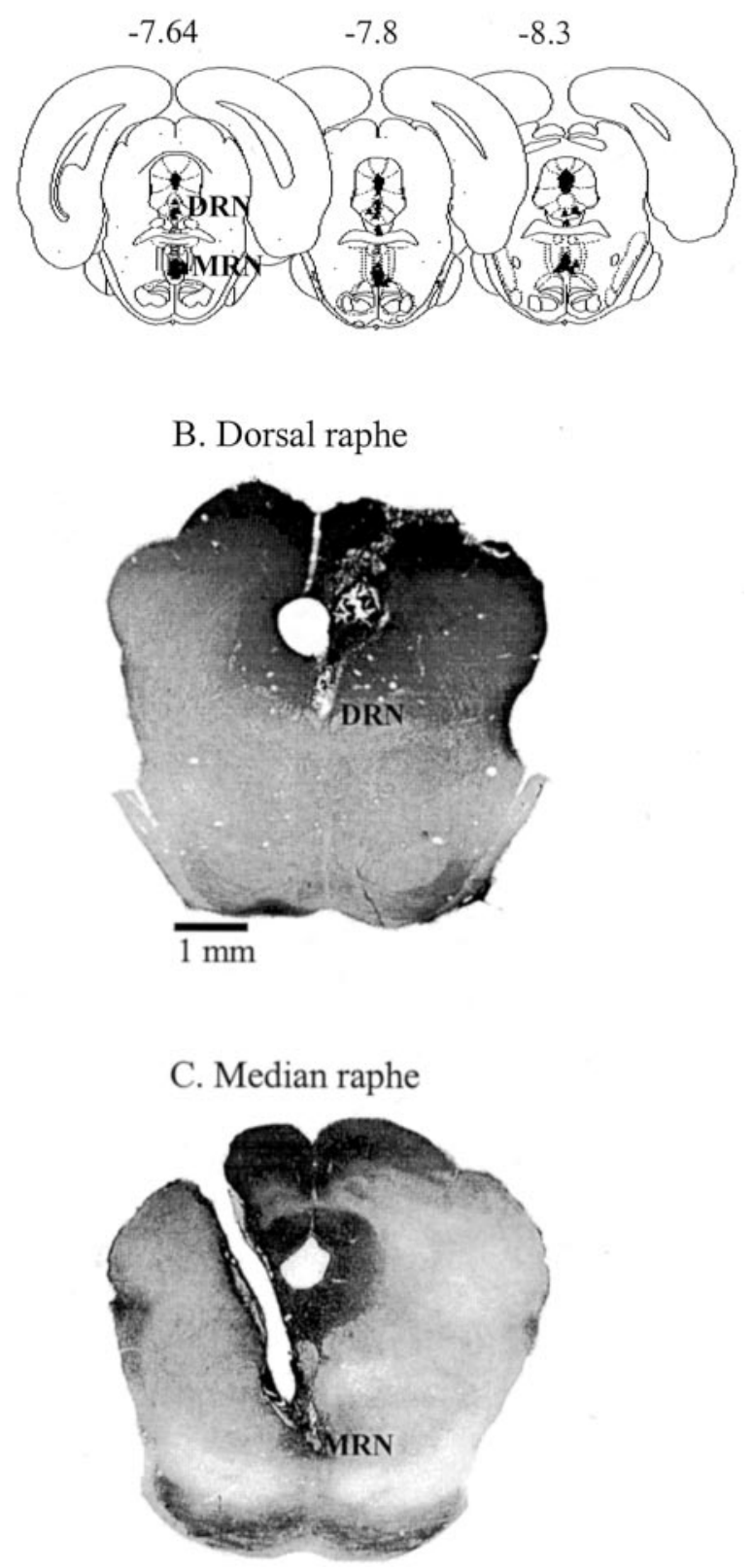

Figure 1. Cannula placements. A, The placements of the tip of the injectors in the DRN and MRN in experiments 1 and 2 (Paxinos and Watson, 1998). B, A pictograph of cannula placement and injector tip in the DRN. $C$, A pictograph of cannula placement and injector tip in the MRN.

the DRN and MRN were as follows: anteroposterior (AP), -7.8 (both sites); lateromedial (LM), 2.4 and 3.1; dorsoventral (DV), 4.9 and 7.0, respectively (Paxinos and Watson, 1998) (Fig. 1A). Lateral ventricle coordinates were as follows: AP, -0.8 ; LM, 1.5; DV, 3.3. Drugs were injected over 45-60 sec with Hamilton syringes connected to 31 gauge injectors extending 1 (ventricle) or 4 (DRN and MRN) $\mathrm{mm}$ below the tip of the guides. The infusion volume was 4 (ventricle) or 0.5 (DRN and MRN) $\mu$ l. Cannula placement was verified histologically, and 19 rats were excluded because of inaccurate placements. The different pharmacological manipulations had no effect on lever-pressing behavior during tests for reinstatement in these rats.

Drugs. $d$-Phe $\mathrm{CRF}_{12-41}$ (Bachem, Torrance, CA), human/rat CRF (Sigma, St. Louis, MO), and 8-OH-DPAT (Sigma) were dissolved in physiological saline.
Training phase. Rats were initially trained to drink alcohol (3-12\% w/v) for $30 \mathrm{~min} / \mathrm{d}$ for $25 \mathrm{~d}$ as described previously (Le et al., 2000). Rats consuming $<0.4 \mathrm{gm} \cdot \mathrm{kg}^{-1} \cdot \mathrm{d}^{-1}$ were excluded. Subsequently, rats were trained to lever press for alcohol $(0.19 \mathrm{ml}$ of $12 \% \mathrm{w} / \mathrm{v}$; each alcohol delivery was accompanied by a light cue for $6 \mathrm{sec}$ ) for $18-25 \mathrm{~d}$ for 60 $\mathrm{min} / \mathrm{d}$ in self-administration chambers equipped with two levers. Responding on one lever (the active lever) activated the infusion pump (Razel Scientific Instruments, Stamford, CT). Presses on the other lever (an inactive lever) were recorded but had no programmed consequences. The response requirements on the active lever were increased from a fixed ratio 1 (FR-1) schedule of reinforcement to an FR-3 schedule (last 8-12 d). Guide cannulas were then implanted, and rats were allowed to recover for $7 \mathrm{~d}$ and were then given five additional training sessions.

Extinction phase. During this phase, lever presses on the active lever were not reinforced. Extinction sessions $(60 \mathrm{~min} / \mathrm{d})$ were conducted for $5-9 \mathrm{~d}$ until the rats reached an extinction criterion of $<15$ presses $/ 60 \mathrm{~min}$ on the previously active lever.

Tests for reinstatement. Tests were conducted under extinction conditions, and drugs were inf used $15 \mathrm{~min}$ before the sessions. In experiment 2, some rats were exposed to $10 \mathrm{~min}$ of intermittent footshock $(0.8 \mathrm{~mA}$, $0.5 \mathrm{sec}$ ON; mean OFF period of $40 \mathrm{sec}$; range of $10-70 \mathrm{sec}$ ) just before the start of the test session (Le et al., 1998).

Experiment 1: 8-OH-DPAT. Two groups of rats were tested for the effect of intra-DRN $(n=15)$ and intra-MRN $(n=16)$ infusions of 8-OH-DPAT $(0.0,0.1,1.0$, and $2.5 \mu \mathrm{g}$; counterbalanced order) on reinstatement of alcohol seeking. Rats were tested every $48-72 \mathrm{hr}$, with regular extinction sessions on the intervening days. Drug doses are based on previous reports (Higgins and Elliott, 1991; Fletcher, 1993).

Experiment 2: CRF and d-Phe CRF. The effect of ventricular inf usions of saline or CRF on reinstatement was determined in two groups of rats $(n=15-16$ per dose). For each group, the effects of saline and one dose of CRF (300 or $1000 \mathrm{ng}$ ) on reinstatement were examined. Rats were tested every $48-72 \mathrm{hr}$ in a counterbalanced order, with regular extinction sessions in the intervening days. The CRF doses are based on a previous report (Shaham et al., 1997). Another group $(n=17)$ was tested for reinstatement after intra-MRN infusions of CRF (0, 3, and $10 \mathrm{ng}$; counterbalanced order). Rats were tested every $48-72 \mathrm{hr}$, with regular extinction sessions in the intervening days. These low doses are based on previous reports (Price et al., 1998; Kirby et al., 2000). A final group $(n=$ $10)$ was tested for the effect of $d$-Phe CRF $(0$ and $50 \mathrm{ng})$ on reinstatement induced by footshock. Each rat was tested, in a counterbalanced order, to vehicle alone, vehicle plus footshock, $d$-Phe CRF alone, and $d$-Phe CRF plus footshock. The $d$-Phe CRF dose is based on a previous report (Erb and Stewart, 1999).

\section{RESULTS}

As in our previous work (Le et al., 1998), rats previously trained to consume alcohol in a two-bottle choice procedure acquired the operant responding for the drug. The mean \pm SEM number of alcohol reinforcements, total responses on the active (reinforcements plus timeout responses) and the inactive levers, and total alcohol intake in the different experiments on the last training session under the FR-3 schedule are shown in Table 1. This table also shows the mean number of non-reinforced responses on the previously active lever and on the inactive lever on the first and last days of extinction. The mean alcohol intake in the different experiments on the last training session was between 0.77 and 1.1 $\mathrm{gm} / \mathrm{kg}$ (Table 1). These values are similar to those obtained in our previous studies (Le and Shaham, 2002).

\section{Experiment 1: 8-OH-DPAT}

Two groups of rats were used to test the effect of 8-OH-DPAT injected into the DRN or the MRN on reinstatement (Fig. 2). For each group, the ANOVA included the repeated-measures factors of 8-OH-DPAT dose $(0,0.1,1.0$, or $2.5 \mu \mathrm{g}$ ) and lever (active or inactive). DRN infusions of 8-OH-DPAT did not increase responding on the active lever. Analyses revealed a main effect of lever $\left(F_{(1,14)}=17.6 ; p<0.01\right)$, but neither the 8-OH-DPAT dose main effect nor the dose by lever interaction were significant. The analysis for the MRN data revealed a significant 8-OH-DPAT 


\begin{tabular}{|c|c|c|c|c|c|c|c|c|}
\hline & \multicolumn{4}{|c|}{ Last $3 \mathrm{~d}$ of training } & \multicolumn{2}{|c|}{ First day extinction } & \multicolumn{2}{|c|}{ Last day extinction } \\
\hline & $\begin{array}{l}\text { Alcohol } \\
\text { intake } \\
(\mathrm{gm} / \mathrm{kg})\end{array}$ & $\begin{array}{l}\text { Alcohol } \\
\text { reinforce- } \\
\text { ments }\end{array}$ & $\begin{array}{l}\text { Active } \\
\text { lever } \\
\text { responses }\end{array}$ & $\begin{array}{l}\text { Inactive } \\
\text { lever } \\
\text { responses }\end{array}$ & $\begin{array}{l}\text { Active } \\
\text { lever } \\
\text { responses }\end{array}$ & $\begin{array}{l}\text { Inactive } \\
\text { lever } \\
\text { responses }\end{array}$ & $\begin{array}{l}\text { Active } \\
\text { lever } \\
\text { responses }\end{array}$ & $\begin{array}{l}\text { Inactive } \\
\text { lever } \\
\text { responses }\end{array}$ \\
\hline \multicolumn{9}{|l|}{ Exp 1} \\
\hline DRN (8-OH-DPAT) & $0.9 \pm 0.07$ & $18.9 \pm 1.5$ & $68.9 \pm 6.4$ & $6.5 \pm 0.9$ & $55.4 \pm 9.2$ & $7.2 \pm 1.5$ & $9.5 \pm 1.6$ & $2.3 \pm 0.9$ \\
\hline MRN (8-OH-DPAT) & $1.1 \pm 0.08$ & $24.5 \pm 1.7$ & $99.9 \pm 6.6$ & $4.9 \pm 0.9$ & $68.4 \pm 9.8$ & $3.1 \pm 1.8$ & $9.4 \pm 1.2$ & $2.5 \pm 1.1$ \\
\hline \multicolumn{9}{|l|}{ Exp 2} \\
\hline ICV CRF & $0.94 \pm 0.04$ & $18.6 \pm 0.9$ & $70.3 \pm 3.5$ & $4.5 \pm 0.6$ & $77.4 \pm 7.1$ & $9.4 \pm 2.2$ & $7.1 \pm 0.9$ & $1.5 \pm 0.4$ \\
\hline MRN CRF & $1.04 \pm 0.06$ & $23.8 \pm 1.4$ & $89.6 \pm 5.6$ & $3.3 \pm 0.6$ & $54.7 \pm 8.1$ & $4.7 \pm 16$ & $9.1 \pm 1.4$ & $4.0 \pm 1.0$ \\
\hline MRN $d$-Phe CRF & $0.77 \pm 0.05$ & $18.4 \pm 1.2$ & $79.9 \pm 6.9$ & $4.4 \pm 1.2$ & $52.3 \pm 8.4$ & $2.2 \pm 0.8$ & $11.4 \pm 1.8$ & $1.3 \pm 0.6$ \\
\hline
\end{tabular}

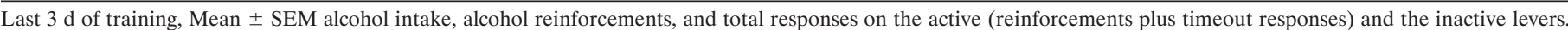

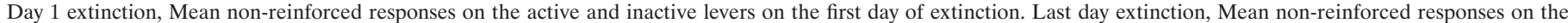
active and inactive levers on the last day of extinction before the start of the tests for reinstatement. Exp, Experiment; ICV, intracerebroventricular.

dose by lever interaction $\left(F_{(3,45)}=3.7 ; p<0.05\right)$. Post hoc analyses revealed that this interaction is attributable to the effect of the $1 \mu \mathrm{g}$ dose on responding on the active lever (Fig. 1B).

\section{Experiment 2: CRF and $\boldsymbol{d}$-Phe CRF} Intracerebroventricular $C R F$

Two groups of rats were tested for the effect of CRF on reinstatement of alcohol seeking (Fig. $3 A$ ). Each group was tested after exposure to the vehicle and one CRF dose. One rat was excluded because the number of responses on the active lever after $1000 \mathrm{ng}$ of CRF (155 responses) was 5 SDs above the mean of its group. ANOVA was conducted with the between-subject factor of CRF dose (3000 or $1000 \mathrm{ng}$ ) and the within-subject factors of pretreatment (vehicle or CRF) and lever (active or inactive). This analysis revealed a significant pretreatment by lever interaction $\left(F_{(1,28)}=5.9 ; p<0.02\right)$ but no effect of CRF dose $\left(F_{(1,28)}=1.5\right.$; NS); both doses of CRF increased responding on the active lever compared with the vehicle condition, and the difference between the two doses was not significant.

\section{$M R N C R F$}

One group of rats was tested for the effect of CRF on reinstatement (Fig. 3B). The repeated-measures ANOVA included the factors of CRF dose (0, 3, or $10 \mathrm{ng}$ ) and lever (active and inactive). This analysis revealed a significant dose by lever interaction $\left(F_{(2,32)}=3.3 ; p<0.05\right)$. Post hoc tests revealed that the significant dose by lever interaction was attributable to the increase in responding on the active lever at the $10 \mathrm{ng}$ dose.

\section{$M R N$ d-Phe $C R F$}

One group of rats was tested for the effect of $d$-Phe CRF on footshock-induced reinstatement (Fig. 3C). The repeatedmeasures ANOVA included the factors of stress (no shock or shock), $d$-Phe CRF dose (0 or $50 \mathrm{ng}$ ) and lever (active or inactive). This analysis revealed a significant three-way interaction of stress by $d$-Phe CRF dose by lever $\left(F_{(1,9)}=18.7 ; p<0.01\right)$. Post $h o c$ analyses revealed that this three-way interaction was attributable to the attenuation of footshock-induced reinstatement of active lever responding in rats pretreated with $d$-Phe CRF.

\section{DISCUSSION}

Our previous data with CRF receptor antagonists and fluoxetine suggest that CRF and 5-HT neurotransmission have opposite effects on stress-induced reinstatement of alcohol seeking (Le et al., 1999, 2000). The present data suggest that these putative
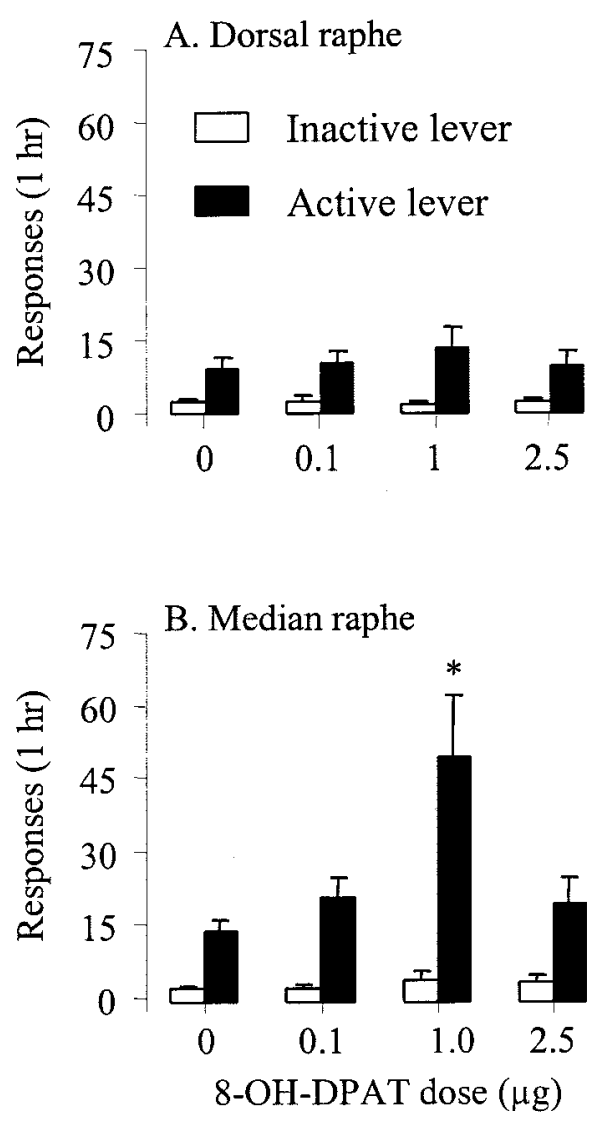

Figure 2. 8-OH-DPAT. Reinstatement of alcohol seeking by MRN, but not DRN, infusions of the $5-\mathrm{HT}_{1 \mathrm{~A}}$ agonist $8-\mathrm{OH}-\mathrm{DPAT}$. Data are mean \pm SEM responses on the previously active lever and responses on the inactive lever on the $60 \mathrm{~min}$ after infusions of 8-OH-DPAT into the DRN $(n=15)(A)$ and MRN $(n=16)(B) .{ }^{*} p<0.05$, different from vehicle.

opposite effects occur, in part, at the 5-HT cell body region of the MRN. Intra-MRN, but not intra-DRN, infusions of 8-OH-DPAT, which inhibits 5-HT cell firing and release, reinstate alcohol seeking. In addition, intra-MRN and intracerebroventricular infusions of CRF mimic to some degree the effect of 8-OH-DPAT on reinstatement. Most important, intra-MRN infusions of a CRF receptor antagonist attenuate footshock-induced reinstate- 

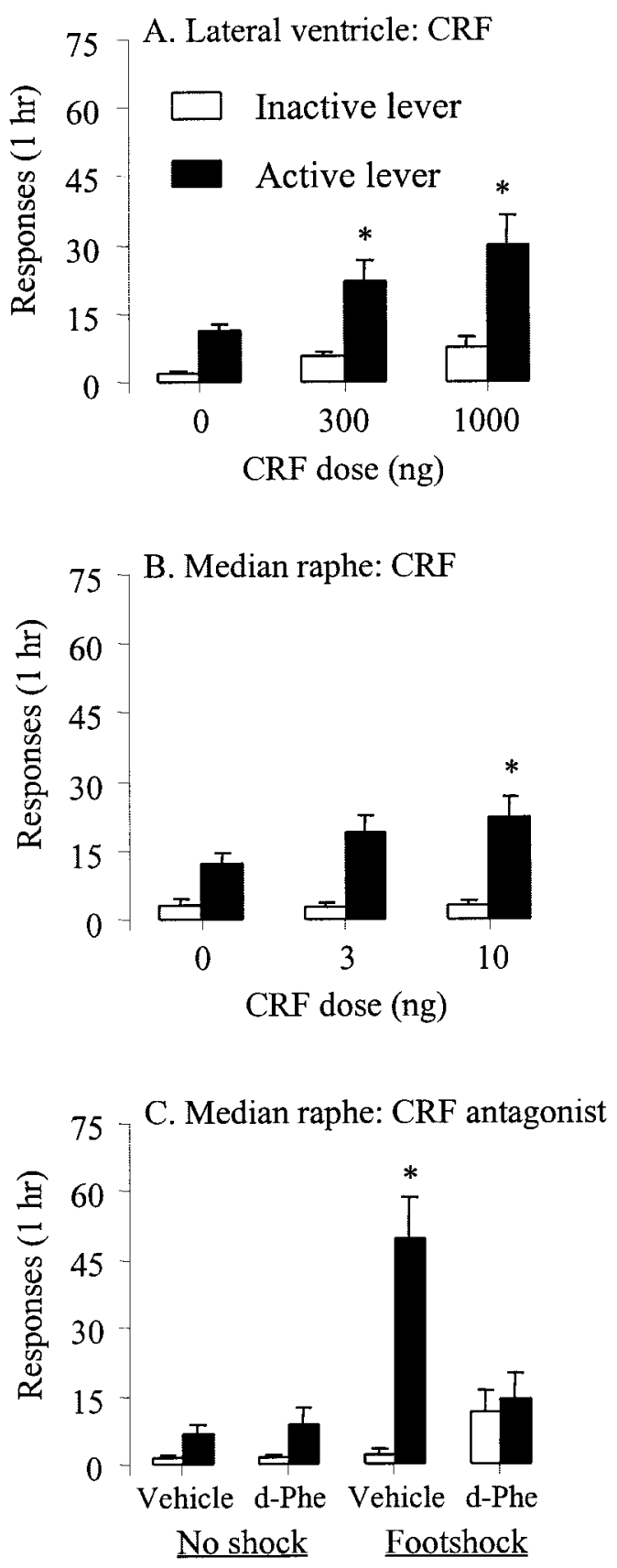

Figure 3. CRF and $d$-Phe CRF. Reinstatement of alcohol seeking by intraventricular and intra-MRN infusions of CRF and blockade of footshock stress-induced reinstatement by intra-MRN infusions of the CRF receptor antagonist $d$-Phe CRF. $A$, Mean \pm SEM responses on the previously active lever and on the inactive lever on the $60 \mathrm{~min}$ after ventricular infusions of vehicle and CRF ( $n=15$ per dose). ${ }^{*} p<0.05$, different from vehicle. $B$, Mean responses on the active and inactive levers on the 60 min after MRN infusions of vehicle and CRF $(n=17) .{ }^{*} p<$ 0.05 , different from vehicle. $C$, Mean responses on active and inactive lever after exposure to $10 \mathrm{~min}$ of intermittent footshock or no shock in rats pretreated with vehicle and $d$-Phe CRF $(50 \mathrm{ng})$ into the MRN $(n=$ 10). ${ }^{*} p<0.05$, different from the other experimental conditions.

ment. These data suggest that an interaction between 5-HT and CRF neurons within the MRN contributes to stress-induced relapse to alcohol seeking.

Although the present study is the first to describe a role of 5-HT in the MRN in alcohol relapse, several studies have exam- ined its role in alcohol consumption. 5-HT lesions of the MRN and DRN did not alter alcohol consumption (Adell and Myers, 1995). However, intra-MRN and intra-DRN infusions of 8-OHDPAT increase alcohol consumption (Tomkins et al., 1994). These effects, however, were only observed at high doses (2.5-5.0 $\mu \mathrm{g}$ ) that do not induce reinstatement (Fig. 2). Here we found an inverted U-shaped dose-response curve for reinstatement after intra-MRN infusions of 8-OH-DPAT, with the most effective dose being $1 \mu \mathrm{g}$. The reasons for the inverted U-shaped doseresponse curve are not clear. However, biphasic responses to 8-OH-DPAT in the raphe nuclei also were observed for conditioned place preference (Fletcher et al., 1993) and locomotor activity (Higgins and Elliott, 1991). The latter study also demonstrated reduced rearing with high doses of 8-OH-DPAT. Thus, motor deficits may interfere with lever-pressing behavior after intra-MRN infusions of the $2.5 \mu \mathrm{g}$ dose. In addition, 8-OH-DPAT is a lipophillic compound and, therefore, can diffuse away from the infusion site. Thus, at high doses, pharmacologically relevant concentrations might reach unintended postsynaptic $5-\mathrm{HT}_{1 \mathrm{~A}}$ receptors. In this regard, an inverted U-shaped dose-response curve is observed after systemic injections of 8-OH-DPAT. Low doses, which preferentially activate the more sensitive $5-\mathrm{HT}_{1 \mathrm{~A}}$ autoreceptors (Mongeau et al., 1997), mimic the behavioral effects of intra-raphe inf usions, whereas higher doses have opposite effects on behavior, presumably attributable to activation of postsynaptic receptors (Poulos et al., 1996). Another methodological issue is that the negative findings with 8-OH-DPAT in the DRN may be attributable to the effect of the drug on motor performance (Higgins and Elliott, 1991). This possibility, however, is unlikely because, at the doses used here, 8-OH-DPAT had no effect on extinction of lever pressing for food (Fletcher, 1993). Finally, it is unlikely that the effect of infusions of the medium dose of 8-OH-DPAT into the MRN on reinstatement (Fig. 2B) is attributable to diff usion to dorsal or distal (if the drug reaches the ventricular space) sites. This conclusion is supported by the findings that 8-OH-DPAT infusions into the DRN, which is both dorsal to the MRN and closer to the aqueduct than the MRN, were not effective (Fig. 2A).

The effects of CRF and $d$-Phe CRF in the MRN on reinstatement of alcohol seeking are consistent with those from studies demonstrating that extrahypothalamic CRF systems are involved in footshock-induced reinstatement of drug seeking (Shaham et al., 2000). The effect of ventricular infusions of CRF on reinstatement of alcohol seeking also extends a previous report using heroin-trained rats (Shaham et al., 1997). Previous studies on the brain sites and neurotransmitters involved in footshock-induced reinstatement of heroin and cocaine seeking have demonstrated that interactions between noradrenaline and CRF in the bed nucleus of the stria terminalis (BNST), and possibly the central nucleus of the amygdala (CeA), are involved in this effect (Shaham et al., 2000). Relevant to the present report are recent studies showing that CRF receptors in the ventral BNST and possibly a $\mathrm{CRF}$ projection from the CeA to the BNST mediate the effect of footshock on reinstatement of cocaine seeking (Erb and Stewart, 1999; Erb et al., 2001). Here we show that CRF receptors in the MRN are involved in the effect of footshock on reinstatement of alcohol seeking. An important issue, which cannot be resolved here, however, is the relationship between the present anatomical findings and those obtained in the studies with cocaine-trained rats. Specifically, an anatomical framework for the present and previous findings is not readily available because the major 5-HT projection to the BNST and CeA is from the DRN (Vertes, 1991). 
CRF neurons innervate the DRN and MRN, and CRF receptors are localized in these areas (Swanson et al., 1983; Chalmers et al., 1995). In the MRN, $\mathrm{CRF}_{1}$ and $\mathrm{CRF}_{2}$ receptors are moderately expressed, whereas in the $\mathrm{DRN}$, the expression of $\mathrm{CRF}_{2}$ receptors is much higher than that of $\mathrm{CRF}_{1}$ receptors (Bittencourt and Sawchenko, 2000; Van Pett et al., 2000). In the posterior DRN, the effect of CRF on 5-HT neurons is primarily excitatory (Lowry et al., 2000; Lowry, 2002), whereas in the anterior-middle DRN, the predominant effect of low to moderate intracerebroventricular doses of CRF $(0.1-1 \mu \mathrm{g})$ or low intraDRN doses (3-10 ng) is neuronal inhibition (Price et al., 1998; Kirby et al., 2000). Data on the effect of CRF on MRN 5-HT neurons are not available. Here we found that intra-MRN infusions of CRF mimic to some degree the effect of 8-OH-DPAT on reinstatement of alcohol seeking. Based on the electrophysiology data described above for the anterior DRN, we speculate that CRF reinstates lever-pressing behavior via its inhibitory effect on 5-HT neurons in the MRN. In addition, as predicted from electrophysiology data demonstrating that CRF only partially inhibits 5-HT cell firing in the anterior DRN (Price et al., 1998; Kirby et al., 2000), we found that the effect of CRF on reinstatement of alcohol seeking is weaker than that of $8-\mathrm{OH}$-DPAT (Figs. $2 B$, $3 B$ ). Finally, although both $\mathrm{CRF}_{1}$ and $\mathrm{CRF}_{2}$ receptors are expressed in the MRN (Van Pett et al., 2000), it is likely that the effects of CRF and $d$-Phe CRF on reinstatement of alcohol seeking observed here are mediated by $\mathrm{CRF}_{1}$ receptors. We and others previously found that a $\mathrm{CRF}_{1}$ receptor antagonist attenuates footshock-induced reinstatement of alcohol, morphine, heroin, and cocaine seeking (Shaham et al., 1998; Le et al., 2000; Lu et al., 2000).

Finally, we speculate that the present data may be relevant for the understanding of the putative association between impulsivity and alcohol abuse and relapse. Impaired functioning of brain 5-HT is associated with deficits in inhibitory control (impulsivity) and was hypothesized to underlie the relationship between impulsivity and human alcohol abuse (Miller, 1991; Linnoila and Virkkunen, 1992). It has also been suggested that processes underlying response inhibition are involved in stress-induced drug-taking behavior (Piazza and Le Moal, 1998; Highfield et al., 2000). The present findings may provide tentative support for this speculation. Thus, the effect of 8-OH-DPAT infusions in the MRN, but not the DRN, on reinstatement of alcohol seeking parallel the effect of intra-MRN 8-OH-DPAT infusions on enhanced responding in several tasks measuring response inhibition (Fletcher, 1993, 1995).

\section{REFERENCES}

Adell A, Myers RD (1995) Selective destruction of midbrain raphe nuclei by 5, 7-DHT: is brain 5-HT involved in alcohol drinking in Sprague-Dawley rats? Brain Res 693:70-79.

Bittencourt JC, Sawchenko PE (2000) Do centrally administered neuropeptides access cognate receptors? An analysis in the central corticotropin-releasing factor system. J Neurosci 20:1142-1456.

Chalmers DT, Lovenberg TW, De Souza E (1995) Localization of novel corticotropin-releasing factor receptor (CRF2) mRNA expression to specific subcortical nuclei in rat brain: comparison with CRF1 receptor mRNA expression. J Neurosci 15:6340-6350.

Erb S, Stewart J (1999) A role for the bed nucleus of the stria terminalis, but not the amygdala, in the effects of corticotropin-releasing factor on stress-induced reinstatement of cocaine seeking. J Neurosci 19:RC35(1-6).

Erb S, Shaham Y, Stewart J (1998) The role of corticotropin-releasing factor and corticosterone in stress- and cocaine-induced relapse to cocaine seeking in rats. J Neurosci 18:5529-5536.
Erb S, Salmaso N, Rodaros D, Stewart J (2001) A role for the CRFcontaining pathway projecting from central nucleus of the amygdala to bed nucleus of the stria terminalis in the stress-induced reinstatement of cocaine seeking in rats. Psychopharmacology 158:360-365.

Fletcher PJ (1993) A comparison of the effects of dorsal and median raphe injections of 8-OH-DPAT in three operant tasks measuring response inhibition. Behav Brain Res 54:187-197.

Fletcher PJ (1995) Effects of combined or separate 5, 7-dihydroxytryptamine lesions of the dorsal and median raphe nuclei on responding maintained by a DRL 20s schedule of food reinforcement. Brain Res 675:45-54.

Fletcher PJ, Ming ZH, Higgins GA (1993) Conditioned place preference induced by microinjection of 8-OH-DPAT into the dorsal or median raphe nucleus. Psychopharmacology 113:31-36.

Higgins GA, Elliott PJ (1991) Differential behavioural activation following intra-raphe infusion of $5 \mathrm{HT}_{1 \mathrm{~A}}$ receptor agonists. Eur J Pharmacol 193:351-356.

Highfield D, Clements A, Shalev U, McDonald RJ, Featherstone R, Stewart J, Shaham Y (2000) Involvement of the medial septum in stress-induced relapse to heroin seeking in rats. Eur J Neurosci 12:1705-1713.

Kirby LG, Rice KC, Valentino RJ (2000) Effects of corticotropinreleasing factor on neuronal activity in the serotonergic dorsal raphe nucleus. Neuropsychopharmacology 22:148-162.

Le AD, Shaham Y (2002) Relapse to alcohol-taking behavior in rats. Pharmacol Ther 94:137-156.

Le AD, Quan B, Juzystch W, Fletcher PJ, Joharchi N, Shaham Y (1998) Reinstatement of alcohol-seeking by priming injections of alcohol and exposure to stress in rats. Psychopharmacology 135:169-174.

Le AD, Poulos CX, Harding S, Watchus W, Juzytsch W, Shaham Y (1999) Effects of naltrexone and fluoxetine on alcohol self-administration and reinstatement of alcohol seeking induced by priming injections of alcohol and exposure to stress in rats. Neuropsychopharmacology 21:435-444.

Le AD, Harding S, Watchus W, Juzytsch W, Shalev U, Shaham Y (2000) The role of corticotrophin-releasing factor in stress-induced relapse to alcohol-seeking behavior in rats. Psychopharmacology 150:317-324.

Linnoila MV, Virkkunen M (1992) Aggression, suicidality, and serotonin. J Clin Psychiatry [Suppl] 53:46-51.

Lowry CA (2002) Functional neuroanatomy of serotonergic systems: implications for neuromodulation of the hypothalamic-pituitaryadrenal (HPA) axis. J Neuroendocrinol, in press.

Lowry CA, Rodda JE, Lightman SL, Ingram CD (2000) Corticotropinreleasing factor increases in vitro firing rates of serotonergic neurons in the rat dorsal raphe nucleus: evidence for activation of a topographically organized mesolimbocortical serotonergic system. J Neurosci 20:7728-7736.

Lu L, Ceng X, Huang M (2000) Corticotropin-releasing factor receptor type I mediates stress-induced relapse to opiate dependence in rats. NeuroReport 11:2373-2378.

Martin-Fardon R, Ciccocioppo R, Massi M, Weiss F (2000) Nociceptin prevents stress-induced ethanol- but not cocaine-seeking behavior in rats. NeuroReport 11:1939-1943.

Miller L (1991) Predicting relapse and recovery in alcoholism and addiction: neuropsychology, personality, and cognitive style. J Subst Abuse Treat 8:277-291.

Mongeau R, Blier P, de Montigny C (1997) The serotonergic and noradrenergic systems of the hippocampus: their interactions and the effects of antidepressant treatments. Brain Res Rev 23:145-195.

Paxinos G, Watson C (1998) The rat brain in stereotaxic coordinates, Ed 4. San Diego: Academic.

Piazza PV, Le Moal M (1998) The role of stress in drug selfadministration. Trends Pharmacol Sci 19:67-74.

Poulos CX, Parker JL, Le AD (1996) Dexfenfluramine and 8-OHDPAT modulate impulsivity in a delay-of-reward paradigm: implications for a correspondence with alcohol consumption. Behav Pharmacol 7:395-399.

Price ML, Lucki I (2001) Regulation of serotonin release in the lateral septum and striatum by corticotropin-releasing factor. J Neurosci 21:2833-2341.

Price ML, Curtis AL, Kirby LG, Valentino RJ, Lucki I (1998) Effects of corticotropin-releasing factor on brain serotonergic activity. Neuropsychopharmacology 18:492-502.

Shaham Y, Funk D, Erb S, Brown TJ, Walker CD, Stewart J (1997) Corticotropin-releasing factor, but not corticosterone, is involved in stress-induced relapse to heroin-seeking in rats. J Neurosci 17:2605-2614.

Shaham Y, Erb S, Leung S, Buczek Y, Stewart J (1998) CP-154, 526, a selective, non peptide antagonist of the corticotropin-releasing factor type 1 receptor attenuates stress-induced relapse to drug seeking in cocaine-and heroin-trained rats. Psychopharmacology 137:184-190. 
Shaham Y, Erb S, Stewart J (2000) Stress-induced relapse to heroin and cocaine seeking in rats: a review. Brain Res Rev 33:13-33.

Shalev U, Grimm JW, Shaham Y (2002) Neurobiology of relapse to heroin and cocaine: a review. Pharmacol Rev 54:1-42.

Sinha R (2001) How does stress increase risk of drug abuse and relapse. Psychopharmacology 158:343-359.

Stewart J, de Wit H (1987) Reinstatement of drug-taking behavior as a method of assessing incentive motivational properties of drugs. In:

Methods of assessing the reinforcing properties of abused drugs (Bozarth MA, ed), pp 211-227. New York: Springer.

Swanson L, Sawchenko P, Rivier J, Vale W (1983) Organization of bovine corticotropin releasing factor immunoreactive cells and fibers in the rat brain: an immunohistochemical study. Neuroendocrinology 36:165-186.

Tomkins DM, Sellers EM, Fletcher PJ (1994) Median and dorsal raphe injection of the 5-HT1a agonist, 8-OHDPAT, and GABAA agonist, muscimol, increase voluntary ethanol intake in Wistar rats. Neuropharmacology 33:349-358.

Van Pett K, Viau V, Bittencourt JC, Chan RK, Li HY, Arias C, Prins GS, Perrin M, Vale W, Sawchenko PE (2000) Distribution of mRNAs encoding CRF receptors in brain and pituitary of rat and mouse. J Comp Neurol 428:191-212.

Vertes RP (1991) A PHA-L analysis of ascending projections of the dorsal raphe nucleus in the rat. J Comp Neurol 313:643-668. 